\begin{tabular}{c} 
Volume and Issues Obtainable at Center for Sustainability Research and Consultancy \\
Journal of Business and Social Review in Emerging Economies \\
ISSN: 2519-089X (E): 2519-0326 \\
Volume 5: No. 1, June 2019 \\
JSRᄃ \\
Journal homepage: www.publishing.globalcsrc.org/jbsee \\
\hline
\end{tabular}

\title{
Restructuring Nigeria: The Dilemma and Critical Issues
}

\author{
${ }^{1}$ Muhammad Fuad bn Othman, ${ }^{2}$ Nazariah binti Osman, ${ }^{3}$ Isah Shehu Mohammed \\ ${ }^{1}$ Lecturer, School of International Studies, Universiti Utara, Malaysia, mfuad@uum.edu.my \\ ${ }^{2}$ Lecturer, School of International Studies, Universiti Utara, Malaysia, nazariah@uum.edu.my \\ ${ }^{3}$ Lecturer, School of General Studies, Federal Polytechnic, Bauchi - Nigeria, zababa72@yahoo.com \\ Email adress: zababa72@yahoo.com
}

\begin{tabular}{|c|c|}
\hline CLE DETAILS & \multirow{9}{*}{$\begin{array}{l}\text { ABSTRACT } \\
\text { Objective: The main objectives of this paper are to explore the critical } \\
\text { issues in the agitations/calls for restructuring Nigeria. A conceptual model } \\
\text { is used and critical issues identified as influenced by many factors and } \\
\text { interests with a special reflections on the background history, geography, } \\
\text { heterogeneity and politics of the Nigerian state. } \\
\text { Methodology: Secondary sources of data were used to and historical } \\
\text { documentation method of data analysis was also used to analyse the data. } \\
\text { Results: There are severally identified issues which are critical to and } \\
\text { must be squarely addressed in order to arrive at a desired and mutually } \\
\text { accepted stand on Nigeria's geo-political, ethno-religious and socio- } \\
\text { cultural composition, and a sustained unity and stability which are sought } \\
\text { in the name of restructuring. Elites and political merchants' prime interest } \\
\text { in power and resources have however, shaped and dominated the } \\
\text { restructuring agitations. } \\
\text { Implications: The study is premised on the socio-economic, political and } \\
\text { ethno-religious realities of the Nigerian state and society. Therefore, the } \\
\text { study presented an outline and a roadmap for the Nigerian policy makers, } \\
\text { politicians, citizens and other stakeholders in the Nigerian state. The study } \\
\text { stated the most sensitive issues which are indispensable to any re- } \\
\text { arrangement, negotiation, consensus and unity in the Nigerian state by the } \\
\text { name of restructuring. }\end{array}$} \\
\hline History & \\
\hline$R e$ & \\
\hline$A 1$ & \\
\hline Key & \\
\hline & \\
\hline Federalism & \\
\hline & \\
\hline & \\
\hline
\end{tabular}

(C) 2019 The authors, under a Creative Commons Attribution-

NonCommercial 4.0

Corresponding author's email address: zababa72@yahoo.com

Recommended citation: Othman, M. F. B., Osman, N. B. and Mohammed, I. S., (2019). The Restructuring Nigeria: The Dilemma and Critical Issues. Journal of Business and Social Review in Emerging Economies, 5 (1), 79-98

DOI: $10.26710 /$ jbsee.v5i1.567

\section{Introduction}

The process of evolution/attainment and development of nation/statehood is not achieved overnight - mistakes are made, lessons are learned; considerations, concession, compromises, sacrifices, loses, and gains are made; symbiotic, parasitic or commensalism relations and co-habitation occur and do change with time and circumstances; conflicts of different dimensions occur and never end, while controversies trail some other issues, even wars are sometimes fought and reconciliations made in the long or short run. This is typical to the Nigerian state, and her evolution and development process. Characteristically, Nigeria, according to Orewa (1997) is a 
calabash floating on a lake and although it may not sink, it has no definite direction/destination; and all chances to fix the Nigerian state at different times are missed, despite the efforts made by her leadership despite the importance of the leadership to every state, society and or organisation (Wooi, Salleh \& Ismail, 2017). Thus, Amuwo, Agbale, Suberu and Herault (2003:137) admit that Nigeria's political development has been dislocated and disrupted and hence, the needs for both structural and institutional coherence. For the longest part of Nigeria's political history, calls/agitations/clamour for constitutional reviews, amendments, conferences, national question, restructuring, among others, have partly dominated the public discourse. The political atmosphere also remains heated from time to time with military interventions and transitions, elections, opposition parties, marginalised elites/politicians/the public, and geo-regional, ethnic and religious groups, among others. These have prompted various constitutions making and re-making; constitutional conferences and amendments; establishment of Constituent Assemblies, MAMSER, National Political Reforms Conference, Oputa Panel, various Revenue Allocation and Minority Commissions, and National Reconciliation Commission (NARECOM), among others.

All the instances identified above have remained manifestations of restructuring/realigning the Nigerian body polity (Suberu, 2015). While some of the challenges are not new, for they have been there since the pre-independence era, but manifesting in different forms and dimensions, in the recent, substantial part of such have consistently came from the South-Western Region of Nigeria, being one of the three major regions that make up the Nigerian entity since the colonial amalgamation of January 1, 1914.

Such calls/agitations have, however been simultaneously defied and resisted by the other parts of the country, specifically, the Northern Region/part until recently. After what may be partly regarded as previous insistence on status quo maintenance, hide and seek play (calls for National Conference and or Sovereign National Conference, General Abacha's Constitutional Conference, 1994, Obasanjo's National Political Reforms Conference, 2005, Jonathan's National Confab, National Reconciliation Commission), virtually every region of Nigeria is now responding to and accepting (willingly or because of political pressure) the quest/calls for the restructuring Nigeria. This restructuring is, however, enveloped in fear, anxiety, hope, despair and desperation, and the elite' interests in continuous access to power and resources, with firm control and consolidation of same. The Northern Region of Nigeria, which had in the past resisted virtually all these calls/agitations for the restructuring is submitting to same, but still with mixed feelings and emotion - feelings among some Northerners that whatever may fall from the heaven, it is time stop the hide and seek and face bull by the horn and let what ever happen.

All the same and with whatever motive, for the restructuring to be meaningful and functional, there are critical issues that must be addressed. This study explored the Nigeria's restructuring dilemma and the critical issues, which must be the focal point of the restructuring for those have been both the unifying and thorny issues in the unity and prosperity of the Nigerian state. The study explored those issues, which form the bedrock of any restructuring/geo-political alignment and balance, and are the determinants of the Nigeria's future in relation to unity, cohesion and stability among the component parts of the state.

\section{Statement of the Problem}

Nigeria, a British make up in 1914, is still carrying and being weighed down by 'burden of difficult history' (Unegbu, 2003; Oliver \& Chandos, 1962). The atmosphere of Nigerian public/political discourse is presently clouded with calls/agitations/clamours for restructuring. Parceled in such calls and agitation's cloud are fears, anxiety, hope, optimism, pessimism, threats, and illusions, among others. Ever since the involuntary amalgamation of various ethno-religious, geo-regional and political nationalities that made up the Nigerian entity on January 1, 1914 , the country has been undergoing one critical socio-economic and political trial or the other. The issues and trends have been messy, characterised by uncertainty, conflicts (sometimes violent), controversy, compromise, and sacrifice. Resistance to the unity and cohesion of Nigeria has also dominated the Nigerian political scene over national question/national conference/restructuring, devolution of powers/true federalism, among others. However, reactions vary from one part of Nigeria to the others. Dealing with the issue has been complex and sensitive having transcend across ethnicities, religions, geo-politics, among others, and also persistent since the amalgamation, colonial and post-independence period as well (Momoh \& Adejumobi, 2017).

Most governments while in power had been resisting such calls/and only play gimmick when much pressurised, some parts of the country have together with the national leadership irrespective of North or South at the headship, resisted and or manipulated such calls/agitations largely due to the questions of constitutionality of such and fear of the known and unknown consequences, including the possible disintegration of the Nigerian state. While some of 
the proponents of the restructuring maintain that anyone who does not benefit from the state has the right to question being part of its unity (Ojukwu, 1989). The leadership, which is essential to the success of every state and society as noted by Wooi, Salleh and Ismail, (2017), therefore, needs to do something to address the situation.

The elites on the other hand, especially who lose out in the political merchandise, keep pressurising for the restructuring; other elites use it as a means to secure political relevance and accommodation in the political space, circle and access to the state power and resources (Adetunberu \& Bello, 2018); the mutual suspicion, fear, despise and resentment, and North/South gap has widened; there is a general feeling of inferiority/superiority complex among the components of the Nigerian federation; some regard others as parasites, and others as betrayers. Poverty, increased manipulation of religion and ethnicity, inability to withstand election defeat, manifesting dissatisfaction with leadership quality, etc., have been further fuelling the agitations/calls for the restructuring. Many of the calls/agitations centre on what Nigerians refer to as 'true federalism' by which they mean a decentralised federation with weak centre and strong component states/regions with resource control autonomy.

There have been consolidating threats to the cohesion, further integration and unity of the Nigerian state with signs and symptoms of not only disaffection, but escalation of insecurities - conflicts over revenue allocation/resource control, cattle rustling, kidnapping, cultism, armed banditry, attacks on oil facilities and installations, bitter politics of ethno-religious and regional identities, ethno-religious intolerances, poverty, ethno-religious, conspired and orchestrated Fulani/herdsmen-farmers conflicts, unemployment, socio-economic and infrastructural deteriorations and above all, corruption. These have altogether also re-engineered and fuelled the disaffection and partly fuelled the calls for Sovereign National Conference, restructuring, etc., in different names and dimensions (Oyadiran \& Toyin, 2015:41; Baba \& Aeysinghe, 2017:42, Mohammed \& Aisha, 2018; Adagbabiri \& Okolie, 2018). With those critical issues and problems, Bello (2018:93) notes that the Nigerian state is on a 'Keg of gunpowder' and needs to do some things to arrest the situation and prevent the country from collapse.

\section{Methodology}

A conceptual model was used and critical issues identified as influenced by many factors and interests with a special reflection on the background, history and politics of the Nigerian state. Secondary sources of data were used to and historical documentation method of data analysis was also used to analyse the data. Much of the data from the secondary sources involved the foundation and formation of Nigeria, the positions of the first generation nationalists, the various historical annals of making and re-making of policies and programmes towards Nigerian unity and cohesion and the complications associated with such.

\section{Theoretical Framework for the Study}

This study is premised on the framework of systems theory which is most suitable for studying a heterogeneous state system, federation and or a complex setting/society/set up where both the political system and its system and sub-systems are inter-dependent on each other in terms of input, output/functions, and what affects one automatically affects the other (Kirchmair, 2017). The systems theory is not limited to the natural sciences only, but also directly linked to the socio-political environment, among others, as the constituents of humankind's existence and survival (Stead \& Stead, 2017). In the systems theory, there are interactions, connectivity, and systematic processing of demands - input and output - policies) (Easton, 1957:384). Nigeria, being a British and heterogeneous making comprises of relatively independent, but interconnected and inter-dependent parts and societies who altogether make up the state and the federation in an arrangement (system) with inter-connectivity with environment, communication, transport, economy, religion, etc., all these are parts of operationalisations of the systems theory (Baecker, 2017; Baraldi \& Corsi, 2017).

The factors of ethnicity, religion, region, culture, etc., all influence and shape the Nigerian system Crawford (1993). More so, Nigerian systemic structure is more properly studied and understood when its heterogeneities are taken into account in relation to the systematic formation of the state itself (McCormick, 2010:445). The systems theory here becomes appropriate and relevant in the context of Nigeria being a federation with sub-systems/structures wishing to restructure the system. Restructuring the Nigerian system is an automatic reflection of the systems theorisations as the sub-systems (component parts, multiple heterogeneities, etc.) are relatively interdependent on one another and an adjustment in one sub-systems affects/alters the system. Restructuring Nigeria, therefore entails adjustments, repositioning, of the heterogeneous constituents which in turn has an overall effect on the Nigerian state system. 


\section{Background of the Nigerian State and Politics}

Nigeria, which resulted from the January 1, 1914 involuntary colonial amalgamation of the Northern and Southern parts of the famous River Niger has since then been faced with numerous challenges of both state/nationhood more than any other country in Africa. Accordingly Kirk-Greene and Rimmer (1981:5) mention such challenges as elites/the masses, North/South, assumed socialism/unitarism, Islam/Christianity, and traditional/achieved authority, but all of which are inconsistent, irreconcilable and characterised by threatening under-currents in the contexts of struggle. The annals of Nigeria's history has the records of the various struggles for inclusion of Nigerians in the colonial government representations; the internal struggle by the various ethno-regional nationalities to ensure their full inclusion and to avoid dominance of one by the others among themselves; the self-government motion and consequent crisis; the various constitutional developments and deadlocks; the crisis of forming coalition governments in 1959 and 1964 federal elections; the Tiv riots in the Northern Region of Nigeria; the Census crisis; the Western Regional Crisis and election; the treason trial of prominent politicians, including Chief Obafemi Awolowo; the January and July, 1966 bloody military coup and counter-coup; the Nigerian civil war; the dominance of military in national affairs; the Murtala coup of July 29, 1975; the transition to civilian democratic regimes and constitution makings; states and local governments creations of 1976; the return of the military to barracks; the president Shagari's economic crisis; the return of the military into politics and governance in December, 1983; the mid 1980's economic crisis and the Structural Adjustment Programme; the 1987 and 1991 states creations; the establishment of MAMSER, the Constituent Assembly and 1989 constitution making; the General Babangida longest and most expensive politics of transition in the history of Nigeria and its failure in 1993; the various ethno-religious conflicts, notably, the 1987 Zangon-Kataf, Kaduna State crisis; the G. G. Orkar coup of April 22, 1990; the June 12, 1993 presidential election and aftermath crisis; the involuntary withdrawal of the military in 1993; the establishment of and the attendant crisis of legitimacy of the Interim National Government; the return of the military in November, 1993; the 1994-95 Constitutional Conference; the 1996 states creation; the General Abacha regime's patchy politics of transition and tenure elongation; the Abdussalami transition and the return of civilian/democratic rule in 1999; the ethno-religious tension and rivalry among Nigerians leading to establishment of the various ethno-militia groups, such as the OPC, APC, MEND, MASSOB; the various resource control battles and politics, including court cases with the Federal and States Government over resource control; the general elections and legitimacy crisis of 2003, 2007 and 2011 elections; oil subsidy scams; the Niger Delta militancy; the Boko Haram insurgency; the orchestrated Fulani/Herdsmen-Farmers conflict; stupendous corruption cases and charges (Rahim \& Toyin, 2018; Mohammed \& Aisha, 2018; Mohammed, Aisha \& Saidu, 2018).

Similarly, Amaechi and Muoh (2017:22) have significantly noted the developments of the pre- independence Constitutional Conference during which the then three regions (East, North and West) reached an agreement to adopt federal system, but with gaps on issues of unity between the north and south, seats allocation in the central legislature based on population, revenue allocation on per capita, Electoral College System, and establishment of the Houses of Chiefs and Assembly.

These and other issues have characterised, dominated and affected the Nigerian state and their recurrences continue to determine and undermine the unity, progress and prosperity of the Nigerian state. Additionally, these cumulatively pose more questions than answers on the feasibility and sustainability of the Nigerian state. Hence, the the calls for restructuring, national conference, national question, reforms, constitutional amendments and reverting to true federalism, among others, which are all disguised, masked or labelled with different names. It could be confidently argued that no state in the world with such heterogeneities as Nigeria and undergoing these cumulative trials, has survived secession, collapse/failure or disintegration. Thus, the submission of Baba and Aeysinghe (2017:42) that Nigeria's unity is faced with multi-dimensioned threats as calls for and attempts to break away/secession, insurgency, farmer-herdsmen/Fulani conflict, cattle rustling, armed banditry, attacks on oil installations, religious intolerance, politics of ethnicity, religion and identity, unemployment and poverty among others. For those reasons, there have been numerous expressions of disaffection by the various elements of the Nigerian state at different times and in different dimensions, but Nigeria has miraculously survived all these and is still united, though of course with many and other emerging challenges. This, however, does not mean Nigeria will automatically continue and remain, and miraculously survive the problems in future as it would be a political and irrational miscalculation to over-stretch its luck.

\section{The Dilemma}


The issue of restructuring Nigeria has on one hand plunged all - the Nigerian state authorities, the elites and the general public into a dilemma. This is because there has not been any format, consensus, harmony and or common ground on what, where, when and by whom to restructure Nigeria. Rather, what obtains is a fraternised Nigeria in which its peoples, elites and state authorities have different perspectives, view and consider the restructuring in relatively opposing and conflicting directions with mainly ethno-religious, sectional, geo-regional and other personal interests over and above the Nigeria and her national interests of unity, cohesion and development; and also rhetoric (Farayibi 2017; Opadere, 2018). For the people of the Middle Belt/Central Nigeria, for example, restructuring Nigeria would mean separating them from the majority Hausa/Fulani/Muslim north, liberating them from centuries of domination, the freedom to create an Christian enclave and practice Christianity, and uplift the minority and mainly Christian tribes from the area. This restructuring is therefore seen by them as the end and success of their struggles to break away from the larger northern Nigeria and hegemony of the Hausa/Fulani and Islam which they have been resisting for centuries. For the Igbo South-East Nigeria, restructuring is an opportunity to even if not actualise their dream of Biafran state, have the opportunity of accessing national political power which they have not since the Ironsi regime was overthrown in 1966, and also exercise domineering power over the South-Eastern part of Nigeria with over-riding economic power. For the South-South/ oil rich Niger-Delta, it is an opportunity to have full (100\%) control of oil resource (Adetunberu \& Bello, 2018). For the North, it is viewed as a threat to the existence of Nigeria as one entity, especially with the anticipated devolution of powers, creation of state police, loss of oil revenue share, etc. To the South-West Yoruba, restructuring is viewed with regionalism, greater regional autonomy/true federalism and economic/resource control in loose federation/weak central and strong regional governments/confederation or any other decentralised arrangement, etc.

On the other hand, the elites from all the geo-political parts of Nigeria have together found a safe and secured market and space for political popularity, access to state power and resources, accommodation, relevance and to divide and rule Nigeria and Nigerians. While the Nigerian state authorities maintain caution, fear and reluctance in handling the issue for it may result in threat to the status quo and political instability as there are thorny issues that must be addressed if the restructuring is to hold. More so, the authorities are fully aware of the legal bounds in doing anything outside constitutional framework and provisions, especially those to do with Nigeria's divisibility and dissolubility (Section 2[1 \& 2] of the Constitution of the Federal Republic of Nigeria, 1999). Despite the dilemma, however, there are common but critical and sensitive issues on which the restructuring must centre around if it is to achieve a meaningful end. This article, therefore, explored the issues.

\section{Politics of Restructuring Nigeria}

It is maintained by Richard Bourne (as cited in Verjee 2017) that 'anyone who claims to understand Nigeria is either deluded, or a liar'. While the calls for restructuring, adoption of true/fiscal federalism, etc., have been on for long in Nigeria, such have been mainly coming from those who are in the opposition, lost out in the political merchandise or dis-advantaged/marginalised in political power and resource sharing and control; and the elites who seek their selfish class interests; while the others, including state authorities resist and turn away from the calls/agitations, except where pushed to the wall. The various regimes while in power had hardly supported the restructuring, but only play gimmicks game and pass on to subsequent incoming regimes. Many of the agitations are also partly dominated by few elites who are more concerned with popularity, politics of accommodation and interested in acquisition, control and consolidation of the state political and economic powers and resources. For the common man, it has remained the same, the various regimes have been the same with little differences and impact on the lives of the ordinary and the down trodden, except in some few cases. At a point, the politics of restructuring has on its own become a means of seeking relevance, resource allocation, political power expropriation and accommodation among the elites. To be precise, politics in Nigeria in both orientation and character, the calls/agitations for restructuring Nigeria and resistance of same, and the calls for national unity are mostly dishonestly driven to achieve certain person interests of the few (Baba \& Aeysinghe, 2017; Farayibi 2017).

All over the world, the ordinary fight, debate, conflict and violence in political and state affairs are left to the common men on street, in the square, ring side or over the streets. This is typical of Nigerian politicians and politics and just in line with Othman (1984) who notes that: "in any struggle for power and its spoils, there is usually a thin line between one's moral position and one's concrete material interests". As for the leaders/elites, although they differ in interests, ideology and have weaknesses and strength, their own is to sit in the political studio, produce, direct, control, follow up and watch over the actions, while the commoners are there on the field/square acting for them, in their interests and on their behalf. Class interest and the quest for and consolidation of political and economic power and resources, and relevance are major factors influencing not only the restructuring agitations in 
Nigeria, but also the also the actions and reactions of the elites/political class globally (Braji, 2014b; Mohammed, 2018; Turner \& Badru, 1984). Therefore, Momoh and Adejumobi (2017) see the restructuring, sovereign national conference, etc., not as the views or meaningful to the toiling people, but the elites and intellectuals feeling about toiling the people.

Like many other past regimes with both lukewarm and reluctant attitudes to the calls, agitations and clamour for the restructuring, in the 2018 New Year broadcast to the nation, Nigeria's President, Muhammadu Buhari (as cited in Blueprint, January 1, 2018, p. 6) depicts that Nigerians are so impatient that they want to move faster than it is possible when it has to take time before a system develops and mature. He further observes that Nigeria's problems are more of process than the much agitated restructuring.

From the other and a different perspective, there are already both legal and political debates, which may ensue to a legal battle over the constitutionality of the restructuring vis-a-vis the powers of the National Assembly, which is constitutionally established to make new, amend existing and or repeal all laws in the Federal Republic of Nigeria under clearly spelt conditions and provisions, and not ethno-regional loyalty, interests, affiliations, such as the Arewa Consultative Forum, ACF, Afenifere, Ohaneze Ndigbo, among others (Sections 4 [1-9], 47, 48 \& 49 of the Constitution of the Federal Republic of Nigeria, 1999). There are fears, nervousness, anxiety and mixed feelings/emotions among all the regions for losing national share of resources - North; anxiety to secede and depend on oil wealth - East; and the confidence to survive with little or without oil by the West. The entire $\mathrm{bid} / \mathrm{clamour}$ for the restructuring is caught with a dilemma over what, who, where when and how to restructure. Aside the realities of the problems bedevilling the Nigerian state, there have not only been manipulations, but also crisis of confidence on the attempts by the authorities to institute mechanisms such as the conference, debate, questions, etc., relating to the restructuring. For example, Agamuo (2014) laments that the 2014 Goodluck Jonathan administration's National Conference was packed up with retired, weak men and women, failed politicians, and retired military officers who have over the years been recycled in such conferences and constitutions making; and also ethno-regional loyalists who are largely responsible for the failures of the Nigerian state and whose major concern was how to share national resources, but not leading Nigeria out of the troubles they had embroiled her into.

Similarly, Baba and Aeysinghe (2017:43) have raised doubt on the sincerity and feasibility of the restructuring for the fact that: "The elites whose supports are required to make disintegration possible are strongly united because the unity of the country seems to be fetching them serious fortunes through corruption and injustice at the expense of the ordinary citizens".

\section{The Nigerian Elite Factor}

There are two broad classes in the society - the elites who are the rulers monopolising power and resource control, but few in number; and the masses who are ruled by the elites, but always larger in number (Peters, 2005:40-44; Mosca, 1939:50). The elites are the few who wield control, consolidate and manage state/societal power and resources in more or less, the interest of the ruled masses. Like many other developing states, politics and statehood in Nigeria are built and hovered around the elites who decide what is to be done, where, when, how and by who. The Nigerian elites also build their networks on patron-client pyramids which ensure both consolidation and transfer of powers from them to their cronies, loyalists and cynics, who carry out the rule on their behalf or at least in servitude to their interests (Draper \& Ramsay, 2008:256). The patron-client relation centres on persons of unequal wealth, status, prestige and influence with dependence for patronage and reward with state power, support, resources and influences (Wilson, 1996:92). The patron-client relation is governed by the collective individual interests of the elites who make up a class for canvassing promoting, consolidating and protecting their collective interests, but do have internal clashes where their individual differences conflict with those of one another - intra class fractions (Mohammed, et al., 2018). The agitations for restructuring Nigeria is partly engineered by the elites, who have lost out in the power change and hand shake game over sometimes in the Nigerian politics. This has manifested in form of raising the dust for restructuring where no political accommodations are offered to such elites upon transition from one government to another or circumstances where appointments into public offices, resource (oil) allocation and control of political power and relevance are lost (Adetunberu \& Bello, 2018). The affected elites then resort to politics of opposition, change and seeking relevance/accommodation, including the calls/agitation for restructuring. On the other hand, the elites vested with state powers at the same time hardly agitate or support such calls/agitations having been with the status quo. This explains why the much and incessant pressure/opposition to governance come from either the opposition, the dis-advantaged or those who feel aggrieved by the existing 
political and economic power structures (Mosca, 1939). To sum up the Nigerian elites character in relation politics, restructuring and unity of the Nigerian state, Baba and Aeysinghe (2017:41) conclude that:

Politics in Nigeria is dishonest in manner and orientation. The calls for negotiations on the terms of national unity are dishonesty-driven. The opposition to negotiation or to call for restructuring is also dishonest. The greater part of the dishonesty is located at the level of the elite. It is precisely the problem of dishonesty that largely informs the agitation for restructuring of the country.

Tied to that, political marketing is now global and the political market needs are everywhere are in the globe and all the stakeholders - governments, politicians the masses, the media, etc., adopt the tools of the market and marketing in order to design and sell products for satisfaction of the political consumers (Wymer \& LessMashment, 2005:1; Baines, 2011:xxi). However, there are numerous manipulations, challenges and intricacies in the market, and sale and consumption of the political products as may be determined by the market (political arena/state), consumers (the public), and the marketers/suppliers (politicians and government) (Sarwate, 1993:8083). Some Nigerian political entrepreneurs have resorted to trading in the restructuring agitations in order to achieve their self-centred ends, but masked in restructuring the Nigerian state. This is typical of elites and politicians, especially in developing states - exploiting every instance, circumstance and opportunity to achieve ends/interests of state political and economic power acquisition, control and consolidation. Indeed, Nigerian elites, political entrepreneurs and agents have consistently employed political scheming, ethnicity and religion to achieve their targets, and thus, an un-ending demand for states and local governments' creations with elites' interests in state power and resources, which also pose other challenges to the Nigerian state (Saylor, 2016; Hislope \& Mughan, 2012).

\section{Federalism in Nigeria}

From October, 1954 to January 1966, Nigeria had operated federal system of government with the powers shared among the Federal, three and later four Regional Governments of the East, North, West and later the Mid-West. However, with the January, 1966 first and bloody military coup, Nigeria was re-directed from federal to unitary system which also lasted for only about six month, then consumed its architect (General Ironsi) and became abolished. Upon assumption of power, General Gowon indicated the imperativeness and desire to return to the federal system, for being the only system that could guarantee the various interests and unity of the Nigerian state and her integral parts, considering its heterogeneous character and complexities. Twelve States (six each for the north and south) and Provinces for each were later in 1967 created which replaced the former and abolished four Regions. Despite its complications and challenges, federalism has so far remained the most feasible option for Nigeria, being a legacy from the British colonialists who in 1914 welded different ethno-religious, geo-political, ethno-cultural and linguistic nationalities into one political entity. Simeon and Conway (as cited in Gagnon and Tully 2001:339) have summarised that the main rationales in federalism are reduction of conflicts, increase in harmony among the component parts, granting autonomy and self-determination and identity by the minorities, and limiting the majority's impositions on the minorities in a reconciled arrangement

Despite the challenges which are inherent in every federal system and arrangement, federalism as a system is a means to an end, but not an end in itself, and the central issue in it lies in how the political actors manage and relate in operating the system (Adedeji \& Ezeabasili, 2018). Thus, Burgess (2006:1) vividly note that both understanding and full comprehension of federalism is not possible, because it (federalism) comprises of some intangible characters, and there is no uniformed means and pattern of operating it in the world and, therefore, strongly asserts that although:

Federal theory does exist, there is, as yet, no fully fledged theory of federalism. At best there is partial theory based on rigorous conceptual analysis and the pursuit of terminological precision. At worst there is crass empiricism rooted in the failure to develop concepts and define the key terms.

Although the 1999 Constitution of Nigeria has no provision for regionalism, one of the issues raised under the current agitations in Nigeria is that of regional autonomy. In the same vein, Riker (1964:142) has maintained that what obliterates and sustains the autonomy of units in a federation is the political culture of the component units. It is pertinent to therefore, note that, even if a change is made and greater powers are given to the component units/states/regions, political culture and observance of the rule of law are more important than anything in achieving the desires of granting autonomy and overall interests of the federalism. 
Therefore, for Ewetan (2012:1084), the central issues bedevilling the Nigerian federal system revolve around the centralist system of fiscal relations; dominance of the Federal Government in revenue sharing from the Federation Account; disharmonious Federal-State relations; critical issue of over dependence on oil revenue; and conflict over revenue sharing principles and formula. It is thus identified that the central points of contention in the Nigerian federalism are the main background of the federalism itself, the cordiality and harmony or otherwise of the intergovernmental relations, the requisites of operating the federalism, the federalism vis-a-vis the other forms of association, the various units in the federal system (states, federal, local, regional, etc.), fiscal matters, political parties (their number, nature and character of establishment and operations), and the strategies for national distribution of services and offices. Despite those however, federalism is so far, the most feasible and alternative arrangement of government in multi-ethnic and geo-religious states as Nigeria, although all the dangers which signalled the collapse of other former federations have been evident in Nigeria (Salawu, Adelabu \& Oladele, 2015). There are, therefore, critical issues and interests in Nigerian federalism which also involve political recognition of the minority, autonomy and access to state power and resources (Adetoye, 2016). Similarly, Daniel (2015), Babalola (2015) and Kalu (2016) assert that Nigerian federalism has over the years been negatively affected by numerous constitutional reviews and amendments, corruption in public affairs, abuse and marginalisation of the minorities and elites' manipulation of state power and resources, and therefore, the call for true federalism in Nigeria ought to commence with re-examining the current constitutional provisions on the federal system, rather than seeking for other alternative arrangements.

\section{Fiscal/True Federalism}

Nigerians have imbibed a tag for a peculiar federal arrangement they clamour for - 'true federalism'. By that term, Nigerians mean a federal system which grants the units more powers than the centre with fiscal responsibilities or rather, the federal arrangement which obtained in Nigeria between 1954 and 1966 when the three and later, the four regions (East, Mid-West, North and West) were constitutionally more powerful than the central government that was limited to less and specific exclusive legislative powers. Rightly observed, however, Azaiki (2007:151) depicts that federalism entails negotiations and sacrifices, and that true federalism results from the deliberate compromises where the autonomous units sacrifice some of their socio-political and economic rights and interests for the overall unity of the sovereign, larger and stronger federation.

In the same vein, Shafritz, Russel and Borick (2007:159-160) have described fiscal federalism as "the fiscal financial relations that exist between and among units of government in a federal system..." and that "the theory of fiscal federalism, or multi-unit government finance, addresses the question of the optimal design of governments in a multilevel (or federal) government system". They additionally note that fiscal federalism is a form of government that is operational in solving the problems of a heterogeneous state, such as the maintenance of high rate of employment with stable prices, equitable distribution of income by the centre, while the other local/regional units handle the allocation of resources for the purposes of local/regional demands. By this submission, the government has an obligation to solve three basic economic problems of attainment of the most equitable distribution of income; maintenance of high employment with stable prices; and establishment of an efficient pattern of resource allocation. This means addressing the question of structural balance/imbalance in resource/revenue allocation among the states and local and the financial autonomy of the units (Amah, 2017).

\section{The Critical Questions in Restructuring Nigeria}

While there are several and diverse reasons for the call/agitations for restructuring the Nigerian state, there are, similarly, critical questions which also require critical and technical answers on the restructuring agenda. These questions border on not only the scope and limitations, but also the legal status of the restructuring and extensively include: what is it to be restructured? The geography of Nigeria? The politics? The People? The state system? Who organises/conducts/regulates the restructuring? Who will represent who, what and where? What is the method of representation? What is the constitutionality or unconstitutionality of the restructuring alongside the Nigerian Constitution and its provisions on the Nigerian state in terms of laws making, repeal and amendments? What is the formula for representation of the ethnic nationalities, regions, states, zones? What will be the terms of reference for the restructuring? Whose constitutional power is it to amend/change the Nigerian constitutional laws? This indeed, are unavoidable questions which require definite and constitutionally backed answers for the restructuring to a both legally and politically binding on the Nigerian state and the citizens (Amaechi \& Muoh, 2017; Rahim \& Toyin, 2018:134; Sections 2, 4, 8, 47, 9[1-4] of the 1999 Constitution of the Federal Republic of Nigeria). 
Restructuring Nigeria, if feasible, would certainly be neither easy nor can it be done within a short time and or process, in addition to various constitutional provisions and limitations on national issues. This is also in view of the sensitivity of the restructuring and the complex nature of the Nigerian state and societies characterised by heterogeneities - socio-political, economic and geo-religious backgrounds, experiences and directions, civilisations and world views. All the same, this study identified the following as the critical issues in restructuring Nigeria.

\section{The Nigerian State, Unity and the Reality}

To understand the significance national unity in any bid to restructuring in Nigeria, it is inevitable to reflect on colonialism, Nigeria's pre-colonial and colonial era. Colonialism has been the main factor responsible for the involuntary reconfiguration of the former African states, Caliphate, Kingdoms, Empires, and mini states, and the reconfiguration of the various peoples geo-ethnic and political settings, which also culminated to colonial and postcolonial ethnic and religious identities of the states and societies (Zahorik, 2017; Ayoade, 2010; Ake, 2000). Furthermore, the colonial policy of divide and rule in Nigeria had made negative impacts on the heterogeneous peoples, who were amalgamated and that further distanced the various ethno-religious and geo-regional groups by derailing their natural form and process of evolution and homogenisation. To make matters worse, the British colonialists deliberately and for their convenience, separated the Northern and Southern Nigeria's administrations which also fostered geo-ethnic tension and disunity in the post-colonial Nigeria. Hence, Nigeria like the other colonised African states is made to carry "the burden of a difficult history" (Jacob, 2012:14). Therefore, what favoured the British political, economic and imperial interests has become a problem for Nigeria, which for over a centenary, could not be solved (Rahim \& Toyin, 2018:134).

Primordial loyalty according to Geertz (1994), is an attachment that stems from the sense of a given social existence - belonging to and or speaking a particular language, following a particular religion, having being born into a particular family/clan, emerging out of a particular circumstances of history, living in a particular place; or the having vital facts on an issue, and in addition to those facts also given other interpretations/meanings from the one's viewpoint as a result of blood relation, speech, customs and traditions, religious perspective, place of residence, historical antecedents, and person's physical appearance. Due to the inter-play of so many factors historical, religious, social, economic, political, and regional, among others, these primordial loyalties have taken over national loyalty in Nigeria and negatively hit the national unity. The extent to which Nigerians have and act within the tendencies of this primordialism has permeated every aspect of Nigeria's national life and this is in line with the submission of Itumo (2017:43) that: "No matter the status of an individual in this country, he has more attachment and loyalty to his indigenous group than to the nation, itself". However, some of the political leaders and elites become involved in such attachments not because they have the conviction that it has any positive impact, but for the fear that their ethno-regional groups may sanction or frown at their inability to canvass their ethno-regional agitations (Adangor, 2017:8).

Nigerian unity has since colonial days been a major challenge to both the nationalists and the ordinary citizens of Nigeria. This is because according to Ojukwu (1989:1) "the problem with Nigeria is that she is fully embroiled in an identity crisis". This identity crisis is rooted in the nature of the colonial conquest and the involuntary weld up of different peoples, nations, states, political and geo-ethnic groups. With that, Nigerians, for example, do not actually perceive and view one another as fellow Nigerians, but 'old time' and 'sworn enemies' (Bello, 2018:93). It is therefore not surprising to face such a challenge. However, the failure over a century to achieve a reliable unity has been the major concern of all. According to Baba and Aeysinghe (2017:41), Nigerian unity and integration process has been marred by many events, especially from 1966 from where some of the federating units became tired and bored of the union, while some others still felt the union must be up held at whatever cost. Although the journey to nationhood/federalism is continuous and mistakes are made, lessons learned and corrections made, the apparent trail of Nigerian state character reflects the inability of the federation to even resolve the basic rudiments which bind and tie the people together. Despite being united for over a century, Nigerians still look back with contemplation of whether to remain in or pull out of the Nigerian federation. The past (violent attempt) by the Biafrans, which was crushed seemed to have been only one out of many, but for the might and legitimacy of the Nigerian authorities to use force and crush any acts and threats of secession and treason from the Nigerian state.

From the varied, but practical conceptions and manifestation of actions of Nigerians, including the elites, the Nigerian unity is conceptualised and worked with differently by Nigerians as observed by Taribo (2014:37-38) that unity in the Nigerian state means different things to Nigerians in their respective regions and ethno-cultural settings. In that respect, to the Hausa/Fulani/North, Nigerian unity means unity in diversity with each part developing at its 
own pace, 'cooperative assistance', and the protection of original and ethno-cultural values in a confederal arrangement; to the Yorubas, Nigerian unity means 'peaceful co-habitation' and 'meritorious development' of each ethno-regional group alongside 'fiscal, political and administrative federalism'; and to the Igbos on the South-East, Nigerian unity means one vast borderless market, unitary administration with freedom to work, residence and the discharge of national civic duties; but for the minorities across Nigeria, unity depicts gang up by the majority ethnic groups (Hausa/Fulani, Yoruba and Igbo) against the minority groups on one hand, and a fierce rivalry between the majority groups that reduced them (minorities) to hostages of the majority groups.

In that regard, Baba and Aeysinghe $(2017 ; 45-46)$ have observed the major threats to Nigerian unity which also relate directly to the restructuring as: poor national governance and leadership; marginalization; religious intolerance; internal conflicts affiliated with ethnic, religion and politics of identity; poor environmental management policy; over centralization of power and resources; corruption; poverty; unemployment; and lack of patriotism. However, to understand the complex nature and character of evolution of Nigeria and other colonised African states, a deep reflection has to be made into the history of colonial conquest, merger and fragmentation of the former pre-colonial states and societies of Africa (Mamdani, 1996).

Thus, Nigeria's first Prime Minister, Sir Abubakar Tafawa Balewa had maintained that ever since the involuntary colonial amalgamation of the Northern and Southern protectorates of the Niger River on January 1, 1914, the country has remained far from being real and united country, but only on paper, because the supposed unity was not originally evolved by the peoples themselves, but mere British desire and interests imposed on the people. Currently, instead of the national unity, loyalty and cohesion, the various ethnic, religious and geo-regional groups are more concerned with the promotion and consolidation of their various particularistic interests, with the dominance of the 'tripod' majority ethnic groups - Hausa/Fulani, Igbo and Yoruba, and the two dominant religions - Islam and Christianity (Asogwa, 2018:49).

There also come the issues of domination, marginalisation, dissention and resentment of one another. On one hand, Nigeria's unity fracas cannot be discerned from the long age nurtured fear of marginalisation and or domination by all the ethnic groups, but especially the oil-rich and other minorities in the Middle-Belt/central Nigeria. In particular, the perceived dominance of the Northern Region of Nigeria over national affairs has remained to date, a major concern of the Southern part as Johnson and Olaniyan (2017:7) note, and all possible means, including violence, calumny, conspiracies, media war had been used in the past to break the Northern hegemony, including the disagreements/deadlocks at the various constitutional conferences, such as the 1950 Ibadan Conference during which the Northern Region insisted on having larger representation in the central legislature, which the South reluctantly agreed to; the attempts to merge Ilorin/Kabba with the Western Region during the First Republic; resistance to quota system; the experience of the January, 1966 Coup, among others, in a struggle/rivalry over political hegemony (Mohammed, Aisha \& Saidu, 2018; Mohammed \& Aisha, 2018; Mohammed, 2018).

Nigeria's unity amidst numerous socio-historic, ethno-religious and geo-political complications, backgrounds and interests form the bedrock and the most critical element that must be traded with both keen interest and caution for the restructuring to hold and achieve any meaningful ends.

\section{Imbalances, Mutual Fears of Domination and Marginalisation}

A critical issue that must be addressed by the restructuring are the both perceived/imagined and real imbalances, domination and marginalisation which have for long resulted in mutual suspicion and fear among Nigerians. The pre-colonial political, economic socio-cultural and religious backgrounds and experiences of the North and West on one hand, and the East on the other; the arrival of the colonialists through the Atlantic Ocean located from the South; the nature and character of the various ethno-religious and geo-political nationalities welded in the January, 1914; the involuntary amalgamation itself; the pattern of colonial domination and rule - direct and direct; the nature and character of colonial socio-economic development; the embedded pattern of educational inequalities between North and South, which persist till today; the primacy of the North in terms of geography and population; and the perceived, feared and resented Northern hegemony in Nigerian politics are all unavoidable variables that resulted in the imbalances of the Nigerian state and culminating to the issues of domination and marginalisation with mutual fears and suspicion among the component parts of the Nigerian federation. These have occupied the political thought and atmosphere of all the regions and discourse of Nigeria (Farayibi 2017), irrespective of whether advantaged or disadvantaged in one aspect or the other. 
Additionally, these have further resulted in not only rivalry and competition, but also attempts to subvert justice, power and resources for self-favour. These factors contribute to what Morganthau (1973), submit that "Any segment of the population which feels itself permanently deprived of its right and full participation in the life of the nation will tend to have lower morale, to be less 'patriotic' than those who do not suffer from such disabilities". It is obvious that there are imbalances, marginalisation and domination, but the controversial questions are "who dominates who, what and how?', 'who marginalises who?' and 'where?' These questions are prompted by the fact that all the ethnic, religious, geo-political, regional and majority/minority groups are marginalised/dominated by others in one way or the others, but the degree of the domination and marginalisation varies from one area, perspective to the other. In addition to that, the cry for fear, domination and marginalisation where there is none has become a means used by Nigerians to attract attention, sympathy and or justify their demands/actions/reactions (Itumo, 2017). To that effect, the minority groups always treat the three majority groups with fear, resentment, dissatisfaction and suspicion, believing that they (the majority) have dominated everything. Likewise, the majority groups (Hausa/Fulani, Igbo and Yoruba) treat one another with suspicion, fear and contempt, believing that each has dominated the others. The fear, domination and marginalisation hold, therefore, on two fronts of majority/minority, and the majority/majority. These have resulted in allegations, counter allegations, accusations, manipulation of figures and facts, fallacies overtaking facts, as well as campaign of calumny over the media and other avenues such as ethnicity and religion, among others. In such a fallacious submission, which also proves the desperation, suspicion and manipulation of the facts and figures, Chris (2014) as cited in (Asaju and Egberi, 2015:131) provides that Hausa/Fulani constitute $70 \%$ of Nigerian soldiers, Hausa/Fulani and Yorubas $-80 \%$ of federal Permanent Secretaries, $80 \%$ of oil wells owned by Hausa Fulani and Yoruba, $60 \%$ of Nigerian military generals are Hausa/Fulani, $60 \%$ of all the heads of federal parastatals are Hausa/Fulani, $60 \%$ of higher ranks in the Nigeria Police, Immigration, Nigeria Ports Authority and Prisons services are each Hausa/Fulani, 70\% of the SSS men, among others.

This is a manifestation of the extent to which the various parts of the Nigerian entity view and treat one another in respect of issues of unity, marginalisation, domination and suspicions, apart from other moves latently made to outwit one another such as breaking the hegemonies, reconfiguring geo-political compositions, and or exploiting the weaknesses of one another in the federation and in the elites' struggle for access and control of political power and resources, such as the Ilorin/Kabba West Merger, the 1962/63 and 1974 Census Crisis (Mohammed, 2018; Mohammed \& Aisha, 2018, Mohammed, Aisha \& Saidu, 2018).

At the earlier stages of Nigeria's federalism and nationhood, the various regional governments of the First Republic had respectively embarked on both latent and manifest programmes and policies to ensure full representation of their regions in the federation and avoid internal domination of their respective intra-regional affairs (Ojo, 2016; Abdulkadir, 2004). In the Northern region, for example, the Regional Premier, Sir Ahmadu Bello embarked on the 'Northernisation Policy', which not only ensured that Nigerians from the other regions, especially the East Igbos were checked in the prior domination of the Northern Public Service and commercial/industrial activities, and a quick, catch up and crash programmes to train the Northerners through both short and long term courses, trainings and up-grading in order to check the excessive domination of the northern public and economic affairs by the nonnortherners and also ensure fair share and representation of the Northern Region at the central level of the federation (Paden, 1986; Clark, 1991; Mohammed, 2018). However, despite the fact that decades have gone since the enactment of that policy, there are still loopholes in the balance of appointments, distribution of resources and dominance of one tribe, section, region or state in the public service and other spheres of the Nigerian state. For example, by 2003, Northern Nigeria, which had more states, local governments and larger population has only about 10 percent of the total number of engineers in Nigeria, 8 percent of the Nigerian banks executives; 15 percent of the total number of Professors; less than 2 percent of insurance practitioners; about 25 percent of Nigerian lawyer/legal practitioners (Adamu as cited in Oyadiran \& Toyin, 2015).

Despite the afterwards developments, and with the inception Federal Character Principle, there still exist imbalances which are more and relatively tilted towards one region against the others in different perspectives (Oyadiran \& Toyin, 2015; Adamolekun, Erero \& Oshionebo, 1991; New Nigerian, January 12, 1999, pp. 13; Weekly Trust, January 19, 1999, p. 12). There are similarly, other areas where the imbalance/character reflects disadvantaged positions to other sides/regions of Nigeria, and each of the geo-political, ethno-religious parts of the country is dis-advantaged and or marginalised in one way or the other, depending on location, type of public service provided, top leadership of the establishment in question and precedence of its pioneer/preceding leadership character. This accentuates the vulnerabilities in the unity and federal arrangement of the Nigerian state and when 
any group/part making up the federation feels marginalised or neglected, its commitment to the union and loyalty to the state are eroded (Adongor, 2017).

The issue of domination in the Nigerian federalism is also enveloped in the control of the central government and the question of who represents the units/tiers/ethnic groups, the modes of representation and the fear of the three dominant ethnic groups by the majority as well as the mutual fear among the three majority groups over the control of the centre, which is strategic to all the units and ethnic groups (Amah, 2017; Ojo, 2016). Many other components of the Nigerian federation, especially from the Northern part/non-oil producing areas, which have over the years defied and resisted the calls/agitations for the restructuring, fear (though mainly off the reality and ignorance political and economic realities and unexplored potentialities of the Nigerian state) the uncertain consequences of the restructuring if held. This fear largely revolves around the question of revenue allocation and how to survive in the restructured Nigeria in the event of adoption of fiscal federalism with autonomy of the lower components of government on resource control.

With the growing fear of both domination and marginalisation, ethno-religious struggles set in, especially in the Middle Belt/Central Nigeria, where religion is used as both the rallying point and instrument of resistance to perceived domination and marginalisation by the Northern minorities, who are largely non-Muslims and the majority Hausa/Fulani/Muslims ethnic group in Northern Nigeria. So also among the Southern minorities, especially the South East, there has for long been the fear and resistance against domination and marginalisation in the Igbo majority region, which became more manifest (with dissent and resentment) during the Nigerian civil war (Taribo, 2014; Osaghae, 1998). That struggle, however, does not involve religion because the South East is largely homogeneous in terms of with Christianity as the most prominent.

\section{Resource Control/Revenue Allocation}

It has been maintained by Alhaji Abubakar Rimi, the former and first elected civilian Governor of Kano State 19791983 (cited in Onu, 1981) that revenue allocation remains a very sensitive and controversial issue, especially in semi-autonomous states with developing economies like Nigeria with both multi-party democracy and different levels of government - the federal, states and the local. The larger portion of the clamour, calls, agitations, and controversy over restructuring in Nigeria centre on resource control and allocation. The assertion by Henry (2007:354) clearly reflects this situation and that the age-long political-economy questions of authoritative allocation of values - who gets what, when and how are more pronounced in the process of revenue allocation between and among components of a government, which is called fiscal federalism, i.e., granting funds by one government to the others for the purpose of attaining some specific policy goals. He further maintains that the keystone of fiscal federalism is "the transfer of funds from one government to one or more other governments in a federation". Hence, the theorists and proponents of fiscal federalism maintain that grants in aid from the central government may be needed in order to supplement the local spending for the national purposes, provision of minimum, uniform services and compensate the citizens in the other areas whose spending/services are beneficial to citizens from the other parts of the federation such as water supply, education and health care (Shafritz, Russel, \& Borick, 2007:160).

In line with that, the resource allocation/revenue sharing formula in Nigeria currently favours the federal/central government (Adedeji \& Ezeabasili, 2018). Foundational to this, Dudley (1982:167) and Elaigwu (1998:6) have also noted and lamented how powers are much concentrated in the federal government (exclusive powers). As a result, the current sharing formula for revenue in the federation which gives $52.68 \%, 26.72 \%$ and $20.60 \%$ for the federal (central), states and local governments respectively, is decried as largely skewed to and driven to the centre, as the Constitution of the Federal Republic of Nigeria, 1999, conferring the Exclusive Powers on the Federal Government with 68 items, including resource control, exploitation and harnessing (Second Schedule [Part I] of Constitution of the Federal Republic of Nigeria, 1999).

Resource control/allocation is therefore, is a critical issue in every meaningful restructuring of Nigeria for it forms the bedrock of and determines the regional, inter-governmental, political and socio-societal settings and relations among the component parts, the citizenry and elites.

\section{A Feasible System of Government}

The systems of government operated by the African states are largely impositions/imports, hence suffer from both misconception and poor operation in the African states systems (Ejiofor, 1981:3-5). Ever since the amalgamation of 
Nigerian state by the British colonial masters in 1914, the search for an acceptable system of government has been on and remained one of the major challenges to the unity, prosperity and development of the Nigerian state. As a result, Nigeria has tried and undergone both the prominent presidential and parliamentary systems, but still remains afflicted by both (Ajulu, 1991:11). Both systems are not devoid of their problems as Hargrove (in Kane, Patapan and Hart 2009:13) assert that both the systems swim against the tides of the dynamics of democracy, but the democracy itself flourishes with time. In Nigeria, the main fear and dilemma that surround the adoption of presidential system is that despite the fact that is easy to form government with stability of tenure, irrespective majority/minority party, it is, however, too expensive and prone to dictatorship, loose party structure and discipline (Shagari, 2001:199, 248, 296; Mohammed, et al., 2018:282-285; Olakunle, 2004:6-7). Specifically, the presidential system is prone to emergence of what Vile (1974:134) calls 'imperial president' although "the exact limit of what the president can do and cannot do, depend upon the circumstances, upon his character, and upon the precise combination of the complementary and off-setting sources of power that face him in a specific situation." This is typical of Nigeria where the president combines the three offices of Head of State, Head of Government and Commander in Chief of the Armed Forces of the Federal Republic of Nigeria (Section 135 of the 1999 Constitution of the Federal Republic of Nigeria).

On the other hand, the parliamentary system, earlier practiced by Nigeria in the late 1950's to mid-1960s is generally less fractious, enables effective and efficient governance, more cost-effective with enactment and flow of policies and information, with strict party/government/opposition structure and discipline, and less dictatorial, constants checks on government and policies by the parliament and the opposition. However, on the other aspect, the government can easily collapse/be voted out (vote of no confidence), there may be delays in formation of government, especially where there is no absolute majority party, and distractions from the official opposition, among others (Malemi, 2010:35-37). Each of the imported systems therefore, has its two faces of advantages and dis-advantages for Nigeria, and pose a dilemma of adoption/adaptation. Nigeria is caught between the two options on one hand and the option provided by Ejiofor (1981:4) of a focused and an internal search with respect to the indigenous socio-political attitudes of Nigerians in order to arrive at a realistic system that would fit into the Nigerian realities and peculiarities, especially that both the presidential and parliamentary have been tested. The dilemma cenres on which of the two systems to adopt/adapt upon restructuring or what alternatives, including an indigenous, but generally accepted system to the heterogeneous Nigerian set up.

\section{Issues of Secularism, Sharia Implementation and Customary Laws}

Religions comprise of two related embodiments in terms of spirituality (transcendence, sacredness and ultimacy); and materially, as a mobiliser and or ginger to achieving social, political objectives. Hardly would therefore, be any religion without interest in socio-political issues in a state (Calvert \& Calvert, 2001:140; Haynes, 2002:116). Nigeria is a secular state (Section 10 of the 1999 Constitution of the Federal Republic of Nigeria), but despite this provision, there is heated controversies, competition and rivalry between Islam and Christianity, and to a lesser extent customary/traditional religions and that has characterised the Nigerian state. Similarly, the issue of Sharia is not new to Nigeria, Nigerians and others who are familiar with its development, especially in the Northern Nigeria, where it has been in practice long before the colonial conquest, domination and coming of Christianity (Ajetunmobi, 2018; Iwobi, 2004; Harnischfeger, 2008). However, for the substantial part of Nigeria's political history, and especially from 1977 with the Murtala/Obasanjo Constituent Assembly (CA) and up to date, the Sharia issue/controversy remains not only heated and threatening, but also a source of fear and phobia, political machinations, elites manipulations and a tool for political and ethno-religious campaign by politicians from both pro and anti-Sharia perspectives, as the issue recurs (Harnischfeger, 2008; Angerbrandt, 2011; Laitin, 1982). This has further been resulting in conflicts and violence masked in religion and Sharia, but having numerous undertones - political interests, elites control, economic advantages and dis-advantages, access to state resources, corruption, among others.

In what Hassan (2015:5) tagged as "the strands of misunderstanding and outright stereotypes", Sharia is seen by many who are ignorant of what it envisages/have its phobia or have subscribed to the anti-Sharia conspiracies and narratives, especially in the recent, as the attempt to by the Muslims, particularly the elements from the Northern Jihadist to continue the Jihadist Dan-Fodio march to Sea with the Holy Qur'an. It has therefore been most sensitive and controversial, and thus the Military in 1977-8, 1989 and 1994 constitutions making made over-rulings with 'no go areas', including the Sharia question (Kendhammer, 2013). To break deadlocks in past constitutions makings and in order to avoid rancour in making processes, the lingering phobia, misconception, political manipulation and conspiracies and narratives prompt the imperativeness of its extensive and intensive deliberations in any 
restructuring bid for the Nigerian state. Although the Sharia at moment involves only the Muslims and adhered to only in Islamic personal laws status and between Muslim litigants, Nigerian Muslims keep agitating for its full implementation, including the Islamic criminal law aspect and establishment of Federal Sharia Courts in order to redirect the limitations of application of full Sharia judgements from states and Sharia courts of appeal, just as there are questions over its criminal aspect applications and clashes between it and the Nigerian constitution/common/English laws in terms of perspectives, content and contexts (Iwobi, 2004; Harnischfeger, 2008). On the other hand and at the same time, however, the non-Muslims, particularly the Christians have through both peaceful and violent avenues consistently resisted the sharia laws and its implementation (Turaki, 1999; Kukah, 1993; Turaki, 1991; Hassan, 2015).

Similarly, the application of Sharia, especially in heterogeneous areas (though it clearly involves only the Muslims wanting to protect their faith), is a source of concern and worthy of an in-depth consideration (Harnischfeger, 2008). The Muslims insist that the essence of Sharia is to preserve the human sanctity, property, family, faith and intellect. The non-Muslims mainly resist Sharia, believing its anti-basic human rights and inflicting inhuman and degrading treatment and punishment on humans, and that it has conferred special treatment to Nigerian Muslims vis-a-vis the others, and the ultimate attempt to dominate the Nigerian political space and marginalise the nonMuslims, and indeed negative stereotyping and false narratives (Anyia, 2017; Harnischfeger, 2008; Quraishi, 2011; Onaiyekan, 1987; Hassan, 2015). Tied to the Sharia and restructuring is the question of customary vis-a-vis the constitutional laws, especially in heterogeneous areas. The Sharia and customary laws have their significance, particularly in resolving deep Islamic/traditional contentions and issues, which the common/constitutional/English laws do not make provisions for or are not popular and sound to handle since the common/English/constitutional laws are alien to the peoples of the Nigerian state. More so, although people resort to the English laws, they (Nigerians) mostly do so where the Sharia/customary laws/traditional provisions fail to address their issues and cases at hand. There is thus a fix and that must be addressed in the restructuring bid, for religion is the most sensitive aspect of lives of the Nigerians, and is the most flashy point exploited by the elites and the political class in their struggle for power and resources, which often results in conflicts, violence and carnages for significant part of Nigeria's history, especially from 1987 (Hassan, 2015).

\section{Structure of the Nigerian State/Federation}

Also a critical issue that relates to the restructuring of Nigeria is whether federal or any other arrangement which could fit into the Nigerian hetrogeneities. Although Nigeria has been operating federal system since October 1954 and even before independence, and Nigerians have in respect of their heterogeneities found a relatively safe haven of being together in federalism aside the British imposition of the system, the questions of the efficacy and continuity of the system and structures of the federation have remained un-answered/un-resolved questions, including the number of levels/tiers, their powers, inter-governmental relations and effective harmony and coordination of functions/powers. All these are in respect of the ethnic tripod character on one hand, and the multitudes of the minority ethnic groups immersed in the federation (Babalola, 2015; Uzodike, Allen \& Whetto, 2010; Amah, 2017; Ibiam, 2016).

\section{Land Tenure System and Administration}

The issue of land is paramount to every community, nation and state and it is a socio-economic and political factor that has a 'non-negotiable necessity', having being a central factor in the socio-political and economic spheres of both individuals and the states (Akinbola \& Yassin, 2017; Eck, 2014). Nigeria has a total land area of 923, 768 sq. $\mathrm{km}$ out of which the usage stands as: $304,843.44$ for arable; 406,457.92 for pastoral; 27,713.04 for permanent crops; 110,852.16 for forest and woodlands; and 73,901.44 for other purposes (Oyetayo, Rahman, Choon, Idowu \& Abidoye (2017). There is however, an un-even distribution of the land area as the Northern region has the vastest land area, and this un-evenness is one of the driving factors of legal, political, communal and inter-governmental conflicts. While the Northern region has this vastest land in addition to population and resources, in comparison the South, which has lesser population and a more compressed land, especially the South Eastern part of Nigeria. Thus, socio-economic, geo-religious and political activities are all determined and or influenced by the North-South geography, land availability and proportion disparities (Arowolo \& Deng, 2018).

The issues of land tenure system, land use act, land administration, though silent in Nigerian state policies and administration, are a very critical and not only affect the economic development of the Nigerian state through agriculture and other economic activities, but also affecting and influencing the socio-cultural and political coexistence and relations among Nigerians (Lawin \& Tamini 2018; Schoneveld, 2017). Issues of indigene/settler, 
allocation/sales/ownership and control of land are inter-twined and all have a direct bearing with one another, including the unity and prosperity of the Nigerian state, especially with diverse political, socio-economic and other interests (Oyetayo, Rahman, Choon, Idowu \& Abidoye, 2017). It has, therefore, remained a major, but a neglected challenge not only to Nigeria, but the African countries with negative effects and continue to threaten productivity, peace, stability and development (Migot-Adholla, Hazell, Blarel, \& Place, 1991; Braimoh, \& Onishi, 2007; Peters, 2004; Platteau, 1996). In Nigeria, for example, it has for long been affecting the peace among communities, states and states and federal government - Ife/Modakeke, Umuleri-Aguleri, Tiv/Jukun, Mwangavul/Ran, Ezillo/EzzaEzillo, Atyap-Hausa/Fulani, Fulani/famers, new anti-grazing laws in some states, in addition to hundreds of thousands of legal cases that have been lying in courts for long (Mohammed, 2018; Mohammed \& Aisha, 2018, Alubo, 2004; Alubo, 2006; Hagher, 2002). There are not only the risks, but the increased insecurity over customary lands in the customary system, which also has bearing on improved economic status (Ghebru \& Girmachew, 2017).

Land tenure system and administration, therefore, features critically in the restructuring for even if the land tenure/customary/administration system will not necessarily be the same all over Nigeria to be restructured, there has to consistent harmony so that economic and other activities and relations, in addition to agriculture and agroallied sub-sectors could be fully exploited, harnessed, secured and guaranteed. This will for ever remain a major determinant and influencing force on peaceful co-existence and relations among Nigerians. In the recent, the controversial Anti-Grazing/Night Grazing Laws in some of the Southern and North-Central/Middle-Belt states have given a dimming light to the peace, security and stability of Nigeria, with continued resistance and clashes between farmers and Fulani/herdsmen on one hand, which is another tip on the age long Umuleri-Aguleri, Ezillo-EzzaEzillo, Tiv/Jukun conflicts all over Nigeria (Mohammed \& Aisha, 2018:27). For the restructuring agenda to achieve optimal objectives, there has to be a thorough exploration and exhaustion of issues on land tenure system with respect to the laws of Land Administration, Land Use Acts, Land Use Decrees, traditional/customary/community land system and structures. Tied to land tenure is the citizenship/indigene/settler controversy and conflict. Land ownership has become a life and death affair among the Africans and specifically Nigerians, as such expropriation of land and its allied resources are knit in indigene/settler in order to include/exclude, deny some and confer its ownership, control, allocation and reallocation on others (Itumo, 2017). This has resulted in conflicts, migrations, relocations in several parts of and across Nigeria and has been claiming thousands of lives for long (Alubo, 2004, Alubo, 2006, Hagher, 2002).

\section{Establishment and Maintenance of Police Force}

The issue of maintaining/establishing the federal, regional and or state/local police is also critical to the restructuring (Ogbo, Obi-AnikeHappiness, Agbaeze \& Ukpere, 2014). Over the years, many states, especially from the southern part of Nigeria have been clamouring for the establishment of states police machineries in the name of combating crime (Bakare, Murana, \& Aliu, 2018; Chinwokwu, 2017). The federal government, however, having been vested with the powers to establish and maintain the Nigeria Police Force, has resisted such clamours for not only going against the subsisting constitutional provisions of Nigeria, but also the possibility of the states turning such to ethno-religious militias and for other particularistic interests, which would result in inter-ethnic, religious, communal, state/federal conflicts (Sections 214-216 of the 1999 Constitution of the Federal Republic of Nigeria). The question/debate arises on whether to maintain the existing federal police force or establish states/regional/local police forces and at whose expense? Under whose control? This is prompted by the First Republic experience during which there Native Police for the regions existing alongside the Federal/Central Police Force (Mohammed, et. al., 2018; 394-395).

\section{The Way forward}

Having identified the critical issues in the agitated restructuring, for Nigeria to achieve a sustained unity, stability and integration, and a successful restructuring by whatever conditions, approach, time and circumstances, there have to be an extensive, intensive, focused and genuine exploration, agreement, consensus, sacrifices and compromises on the critical issues raised in this study. In addition to those, good governance at all levels; inclusiveness of all Nigerians irrespective of differences; ethnic and religious tolerance among the parts of the federation; sound socio-economic and environmental policies; determined fight against poverty and corruption, unemployment and national loyalty and patriotism; and re-allocation of the constitutional powers are indispensable to the continuity, integration and development of the Nigerian state and federalism.

\section{Summary and Conclusion}


All the politics in Nigeria among the elites is about the struggle to access and consolidate the hold of political power and state resources. This, however, there are also rationales behind the clamour/calls/agitations for restructuring in Nigeria, although the square/battle field of Nigerian politics is largely attended more by the poor, deprived masses, the downtrodden and dejected, the illiterate and ignorant, etc., while the real architects, masters and managers of the political and economic games and affairs are the elites who know themselves and no matter what happens between and among them, they, despite their internal fractions at certain points reach areas of collaboration, connive, reach consensus, make compromises to host, accommodate one another and further grip the political and economic powers of the Nigerian state. Meanwhile restructuring is one of their resorts to such. Restructuring would however, benefit Nigeria and Nigerians if truly the critical issues of ethnicity, religion and identity, marginalisation, resource control, revenue allocation, autonomy of regions/state, inclusiveness in decisions making, citizenship/indigeneship, establishment and roles of state/regional/central police, devolution of powers, land tenure system/use act, secularism/sharia/state religion are addressed. It is the ability/inability to fully consider and resolve these issues that would determine the validity, reliability and success or failure of the restructuring.

\section{References}

Abdulkadir, A. T. (ed.). (2004). Makers of northern Nigeria: A compendious account of the virtuous titans that built the north and steered it to its sunshine of glory. Kaduna Nigeria: De Iman Ventures.

Adagbabiri, M. M., \& Okolie, U. C. (2018). Federalism and political restructuring in Nigeria: The Panacea for mutual coexistence and management of nation's resources. Journal of International Social Research, 11(59), 304-319.

Adamolekun, L., Erero, J. \& Oshionebo, B. (1991), Federal character and management of the federal civil service and the military. Publius: The Journal of Federalism, 21. 75-88.

Adangor, Z. (2017). Separatist Agitations and the Search for Political Stability in Nigeria. Donnish Journal of Law and Conflict Resolution, 3(1). 1-17.

Adedeji, A. O. Ezeabasili, I. E. (2018).Restructuring and clamour for 'True' federalism in Nigeria: A comparative analysis. Advances in Social Sciences Research Journal, 5(2), 160-168.

Adetoye, D. (2016). Ethnicity and state creation in Nigeria: exploring the nexus between the Babel of tongues and institutionalization. International Journal of Economics, Commerce and Management, IV (4), 1-12.

Adetunberu, O., \& Bello, A. O. (2018). Agitations in the Niger Delta region, oil politics and the clamours for restructuring in Nigeria. International Journal of Peace and Conflict Studies (IJPCS) 5(1), 115-125.

Agomuo, Z. (2014). As national conference winds down, what hope for Nigeria? Business Day, June 29. [Online] Available: https://www.businessdayonline.com/as-national-conference-winds-down-what-hope fornigeria-2/ (October 15, 2015).

Ajetunmobi, M. A. (2018). Sharia legal practice in Nigeria 1956-1983. Ilorin, Nigeria: Kwara State University Press.

Ajulo, B. S. (1992). The president in council: Evolution of the federal council secretariat. Lagos: Malthouse Press.

Akinbola, K. B., \& Yassin, A. M. (2017). Contextualisation of the 'brickwalls'of land administration and regulation system affecting the dynamics of formal land market in Nigeria. European Journal of Economic and Financial Research, 2(2), 73-91.

Alubo, O. (2004). Citizenship and Nation-Making in Nigeria: New Challenges and Contestations. Lagos: PEFS.

Alubo, O. (2006). Ethnic conflicts and citizenship Crises in the central region. Ibadan: Programme on Ethnic and Federal Studies (PEFS).

Amaechi, C. M. \& Muoh, O. U. (2017). Constitution building as a panacea to identity conflicts in Africa: The case of Nigeria. Mediterranean Journal of Social Sciences, 8(4), 17-26.

Amah, E. I. (2017). Federalism, Nigerian federal constitution and the practice of federalism: An appraisal. Beijing Law Review, 8(3). 287-310.

Amuwo, K, Agbale, A., Suberu, R., \& Herault, G. (Eds.). (2003). Federalism and Political Restructuring in Nigeria. Ibadan: Spectrum Books.

Angerbrandt, H. (2011). Political decentralisation and conflict: the Sharia crisis in Kaduna, Nigeria. Journal of Contemporary African Studies, 29(1), 15-31.

Anyia, A. (2017). Muslim organisation and the mobilisations for Sharia law in northern Nigeria: The JNI and the NSCIA. Journal of Asian and African Studies, 52(1), 82-102.

Arowolo, A. O., \& Deng, X. (2018). Land use/land cover change and statistical modelling of cultivated land change drivers in Nigeria. Regional Environmental Change 18(1), 247- 259.

Asaju, K. \& Egberi, T. (2015). Federal character and national integration in Nigeria: The need for discretion and 
interface. Review of History and Political Science, 3(1), 126-134.

Asogwa, J. O. (2018). Federalism and governance in Nigeria. Online journal of arts, management \& social sciences, 3(1) 48-54.

Azaiki, S. (2007). Inequities in Nigerian politics: The Niger-Delta, resource control, underdevelopment and youth restiveness. Ibadan: Y Books.

Baba, I., \& Aeysinghe, C. (2017). Re-positioning Nigeria towards sustainable national unity. Global Journal of Human-Social Science Research, 17(4), 40-49.

Babalola, D. (2015). The efficacy of federalism in a multi-ethnic state: the Nigerian experience. Journal of Pan African Studies, 8(2). 74-91.

Baecker, D. (2017). Systems Are Theory. Cybernetics \& Human Knowing, 24(2), 9-39.

Baines, P. R. (ed.). (2011). Political marketing: Concepts and theories. London: Sage. (Volume I).

Bakare, A. R., Murana, A. O., \& Aliu, F. O. (2018). State policing in Nigeria: A response to emerging trajectories of conflict and crime? Journal of African-Centred Solutions in Peace and Security 2(1). 113-132.

Baraldi, C., \& Corsi, G. (2017). Social Systems Theory. In Niklas Luhmann (pp. 11-36). Springer, Cham.

Braimoh, A. K., \& Onishi, T. (2007). Spatial determinants of urban land use change in Lagos, Nigeria. Land Use Policy, 24(2), 502-515.

Braji, I. (2014). The Nigerian military: Origins, politics and capital accumulation. Ibadan: University Press.

Burgess, M. (2006).Comparative federalism: Theory and practice. London: Routledge.

Calvert, S \& Calvert, P. (2001). Politics and society in the third world (2nd ed.). Harlow: Pearson Education.

Chinwokwu, E. C. (2017). Managing police personnel for effective crime control in Nigeria. International Journal of Police Science \& Management, 19(1), 11-22.

Clark, T. (1991). A right honourable gentleman: The life and times of Sir Abubakar Tafawa Balewa. Zaria: Huda-Huda Publishing Company.

Constitution of the Federal Republic of Nigeria 1999. Lagos: Government Printer.

Crawford, Y. (1993). The politics of cultural pluralism. Ibadan: Heinemann Educational Books Ltd.

Daniel, M. M. (2015). Responsiveness to housing and urban development policy decisions in Nigeria's federation: the case of Jos city. Urban Forum, 26 (4), 483-502.

Draper, A. \& Ramsay, A. (2008). The good Society. New York, NY: Pearson Education Books.

Dudley, B. J. (1982). An introduction to Nigerian government and politics. Lagos: The Macmillan Press.

Easton, D. (1957). An approach to the analysis of political systems. World politics, 9(03), 383-400.

Eck, K. (2014). The law of the land: Communal conflict and legal authority. Journal of Peace Research, 51(4), 441-454.

Ejiofor, I. U. (1981). Dynamics of Igbo democracy. Ibadan: University Press Limited.

Elaigwu, J. I. (1998). Federalism under military regime: The need for national unity in a diverse Nigeria. London: Macmillan.

Ewetan, O. O. (2012). Fiscal federalism in Nigeria: Theory and practice. International Journal of Development and Sustainability, 1(3), 1075-1086.

Farayibi, A. O. (2017). The structure of Nigeria's restructuring rhetoric. National discourse. Centre for Allied

Research and Economic Development Ibadan, Oyo State, Nigeria, ND002/September, p. 1-18.

Gagnon, A. \& Tully, J. (eds.). (2001). Multinational democracies. Cambridge: Cambridge University Press.

Geertz, C. (1994). Primordial loyalities and Standing Entities: Anthropological Reflections on the Politics of Identity, Budapest/HUN: Collegium, Budapest: Institute for Advanced Study.

Ghebru, H., \& Girmachew, F. (2017). Synopsis: Scrutinizing the status quo: Rural transformation and land tenure security in Nigeria (No. 45). International Food Policy Research Institute (IFPRI).

Hagher, I. (2002). Beyond Hate and Violence: Understanding the Tiv Struggle for Citizenship Rights and Social Justice in Nigeria. Ibadan: Caltop Publications.

Harnischfeger, J. (2008). Democratization and Islamic law: The sharia conflict in Nigeria. Frankfurt: Campus Verlag.

Hassan, I. H. (2015). An introduction to Islamic movements and modes of thought in Nigeria. Programme for African Studies, Northwestern University, Institute for the Study of Islamic Thought in Africa (ISITA).

Haynes, J. (2002). Politics in the developing world: A concise introduction. Oxford: Blackwell Publishing.

Henry, N. (2007). Public administration and public affairs. New Jersey: Pearson Prentice Hall. (Tenth Edition).

Hislope, R. \& Mughan, A. (2012). Introduction to comparative politics: the state and its challenges. New York: Cambridge University Press.

Ibiam, A. E. (2016). Federalism, Democracy and Constitutionalism: The Nigerian experience Journal of Law, 
Policy \& Globalization, 53(2), 1-14.

Itumo, A. (2017). Indigeneity and citizenship questions in Nigeria. African Journal of Politics and Administrative Studies, 6(1), 1-15.

Iwobi, A. U. (2004). Tiptoeing through a constitutional minefield: The great Sharia controversy in Nigeria. Journal of African Law, 48(2), 111-164.

Kalu, J. O. (2016). True federalism? Illustrations with the Venn diagram. European Scientific Journal, 12 (8).

Kane, J., Patapan, H., \& Hart, P. (eds.). (2009). Dispersed democratic leadership: Origins, dynamics \& implications. New York, NY: Oxford University Press.

Kendhammer, B. (2013). The Sharia controversy in northern Nigeria and the politics of Islamic law in new and uncertain democracies. Comparative Politics, 45(3), 291-311.

Kirchmair, L. (2017). Mathias Albert. A Theory of World Politics. European Journal of International Law, 28(2), 658-663.

Kirk-Greene, A. \& Rimmer, D. (1981). Nigeria since 1970: Political and Economic Outline. London: Hodder and Stoughton.

Kukah, M. H. (1993). Religion, Politics, and Power in northern Nigeria. Ibadan, Nigeria: Spectrum Books Limited.

Laitin, D. D. (1982). The Sharia debate and the origins of Nigeria's second republic. The Journal of Modern African Studies, 20(3), 411-430.

Lawin, K. G., \& Tamini, L. D. (2018). Land Tenure Differences and Adoption of Agri-Environmental Practices: Evidence from Benin. The Journal of Development Studies, 1-14.

Malemi, E. (2010). The Nigerian constitutional law. Lagos: Princeton Publishing Company.

McCormick, J. (2010). Comparative politics in transition. Boston: Wadsworth Cengage Learning.

Migot-Adholla, S., Hazell, P., Blarel, B., \& Place, F. (1991). Indigenous land rights systems in sub-Saharan Africa: a constraint on productivity? The World Bank Economic Review, 5(1), 155-175.

Mohammed, I. S. \& Aisha, A. A. (2018). Fulani/herdsmen-farmers conflict in Nigeria: The emerging dimensions, complications and the Theatre. Beau Bassin, Mauritius: Lambert Academic Publishing.

Mohammed, I. S. (2018). Integrated profile of northern Nigeria. Beau Bassin, Mauritus: Lambert Academic Publishing.

Mohammed, I. S., Aisha, A. A., \& Saidu, A. (2018). Nigerian political development. Beau Bassin, Mauritus: Lambert Academic Publishing.

Momah, S. (2013). Nigerian beyond divorce. An amalgamation in perspective. Ibadan: Safari Books.

Momoh, A., \& Adejumobi, S. (eds.). (2017). The national question in Nigeria: Comparative perspectives. New York, NY: Routledge.

Morganthau, H. J. (ed.). (1973). Politics among nations: The struggle for power and peace. New York: Alfred A. Knoff, Inc. (5th Edition).

Mosca, G. (1939). The ruling class. New York, NY: McGraw-Hill.

Ogbo, A. I., Obi-AnikeHappiness, O., Agbaeze, E. K., \& Ukpere, W. I. (2014). Strategic restructuring for effective police system in Nigeria. Journal of Governance and Regulation, 3(4), 163-173.

Ojo, E. O. (2016). The Awolowo-Akintola leadership tussle: A reinterpretation. Journal of Arts and Humanities, 5 (1), 76-90.

Ojukwu, E. O. (1989). Because I am involved. Ibadan: Spectrum Books.

Olakunle, T. (2004). How our laws are made. Lagos. Centre for Free Speech.

Onaiyekan, J. O. (1987). The Sharia in Nigeria: A Christian View. Bulletin on Islam and Christian-Muslim Relations in Africa, 5(3), 1-17.

Onu, E. (ed.). (1981). Struggle for redemption: Selected speeches of Muhammadu Abubakar Rimi. Zaria: Northern Nigeria Publishing Company.

Opadere, O. S. (2018). Perspectives to restructuring Nigeria in the search for legally viable means of extrication. Journal of Law, Policy and Globalisation, 73, 157-188.

Orewa, O. G. (1997). We are all guilty: The Nigerian crisis. Ibadan: Spectrum Books.

Osaghae, E. E. (1998). Managing multiple minority problems in a divided society: The Nigerian experience. The Journal of Modern African Studies, 36(1), 1-24.

Othman, S. (1984). Classes, crisis and coup: The demise of Shagari's regime. African Affairs, 83(333), 441-461.

Oyadiran, P. \& Toyin, S. O. (2015). Federal character and political integration in Nigeria. Global Journal of Political Science and Administration, 3(4), 37-50.

Oyetayo, B. S., Rahman, A., Choon, L. T., Idowu, T. O., \& Abidoye, A. I. (2017). Land Administration Domain Model in Review towards the Adoption as a Reference Model for Land Administration System in 
Nigeria. American Journal of Geographic Information System, 6(5), 178-186.

Paden, J. N. (1986). Values and leadership in Nigeria: Ahmadu Bello Sardauna of Sokoto. Zaria: Huda-Huda Publishing Press.

Peters, P. E. (2004). Inequality and social conflict over land in Africa. Journal of agrarian change, 4(3), 269-314.

Platteau, J. P. (1996). The evolutionary theory of land rights as applied to sub-Saharan Africa: a critical assessment. Development and change, 27(1), 29-86.

Quraishi, A. (2011). What if Sharia weren't the enemy: rethinking international women's rights advocacy on Islamic law? Columbia Journal of Gender \& Law, 22, 173-184.

Rahim, A. \& Toyin, C. A. (2018). Inclusive Governance in Ethnically Divided Nigeria since 1999: The Application of the Principle of Federal Character and Power Sharing System. Greener Journal of Social Sciences, 3(3), 133-144.

Riker, W. (1964). Federalism: origin, operation, significance. Boston: Little Brown.

Salawu, M. L. \& Adelabu, A. \& Oladele, E. (2015). Ethnicity: Historical similarities between Yugoslavia and Nigeria. Scottish Journal of Arts, Social Sciences and Scientific Studies, 27, (I).

Sarwate, D. M. (1993). Political marketing: the Indian experience. New Delhi: Tata McGraw-Hill.

Saylor, R. (2016). Ethnic entrepreneurs and movements for new administrative units: Lessons from Nigeria. The Journal of Federalism, pjw016.

Schoneveld, G. C. (2017). Host country governance and the African land rush: 7 reasons why large-scale farmland investments fail to contribute to sustainable development. Geoforum, 83, 119-132.

Shafritz, J. M., Russel, E. W., \& Borick, C. P. (2007). Introducing public administration. New York: Pearson Education. (Fifth Edition).

Shagari, S. (2004). Shehu Shagari: Beckoned to serve, an autobiography. Ibadan: Heinemann Educational Books.

Stead, J. G., \& Stead, W. E. (2017). Management for a small planet. New York, NY: Routledge.

Suberu, R. (2015). Managing constitutional change in the Nigerian federation. Publius: The Journal of federalism, 45(4). 552-579.

Taribo, S. M. K. (2014). Federal character principle and destiny of Nigeria. Port-Harcourt-Nigeria: Spiff Micah K. Taribo.

Turaki, Y. (1993). The British colonial legacy in northern Nigeria: A social and ethical analysis of the Colonial and post-colonial society and politics in Nigeria. Jos: Quarness Publishers.

Turaki, Y. (1999). Theory and practice of Christian Missions in Africa: A Century of SIM/ECWA history and legacy in Nigeria 1893 - 1993 (Volume One). Nairobi, Kenya: International Bible Society Africa.

Turner, T. \& Badru, P. (1984). Oil and instability: Class contradictions and the 1983 coup in Nigeria Journal of African Maxists, 7, 4-21.

Unegbu, O. (2003): Nigeria: Bellwether of African Democracy. World Policy Journal, 20(1), 41-48.

Uzodike, U. O., Allen, F., \& Whetho, A. (2010). Making Nigerian Federalism Work. Loyola Journal of Social Sciences, XXIV (2), 161-185.

Verjee, A. (2017). Nigeria: a new history of a turbulent century, International Affairs, 93, 5(1), 1278-1279.

Vile, M. J. C. (1974). The presidency. London: George G. Harrap \& Co.

Wooi, C. T., Salleh, Z. M. \& Ismail, I. S. (2017). Lessons from major leadership theories in comparison to contemporary theory for leadership practice. Journal of Business and Social Review in Emerging Economies 3(2), 147-156.

Wilson, F. L. (1996). Concepts and Issues in comparative politics: An introduction to comparative analysis. New Jersey, NJ: Prentice Hall.

Wymer, W. W. \& Lees-Marshment, J. (eds.). (2005). Current issues in political marketing. New York, NY: Best Business Books.

Newspapers

Albashir, A. (1999, January 19). Effect restructuring, shift transition' - Abdulkarim Albashir. Weekly Trust, p. 12.

New Nigerian, (1999, January 12). Who is afraid of power shift and true federalism? (I). New Nigerian, p. 13.

Buhari, M. (2018, January 1). Restructuring not solution to our problems. Blueprint, p. 6. 